Jaeda C. Calaway

\title{
The Sabbath and the Sanctuary
}

\section{Access to God in the Letter to the Hebrews and its Priestly Context}

[Der Sabbat und das Heiligtum. Der Zugang zu Gott im Hebräerbrief und sein priesterlicher Kontext.]

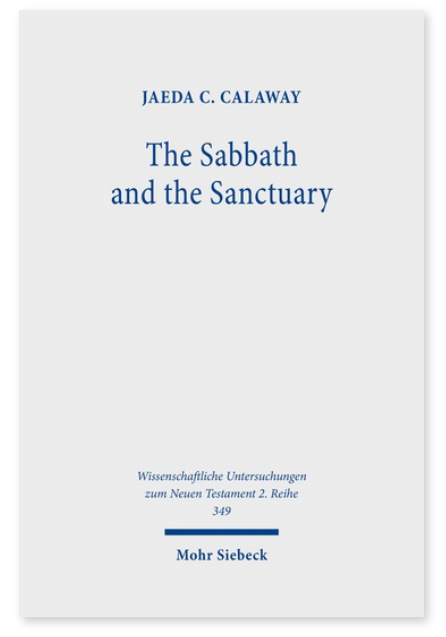

2013. XIII, 250 Seiten. WUNT II 349

ISBN 978-3-16-152371-7

DOI 10.1628/978-3-16-152371-7

eBook PDF 94,00€

ISBN 978-3-16-152365-6

fadengeheftete Broschur 94,00€
Veröffentlicht auf Englisch.

Wer erhält Zutritt zur heiligen und himmlischen Gegenwart Gottes? Und wie? Verschiedene antike jüdische und aufstrebende christliche Gruppierungen diskutierten diese Fragen im ersten Jahrhundert n. Chr. Jaeda C. Calaway stellt fest, dass der Hebräerbrief sich der Diskussion anschloss, indem er das priesterliche, dezidiert sakrale Bezugssystem, das den Sabbat auf das Heiligtum ausrichtete, in Anspruch nahm. Von der hebräischen Bibel bis zum Judentum zur Zeit des zweiten Tempels wurde die Heiligkeit des Altarraums durch den Sabbat erlebt, heilige Orte durch heilige Zeiten. In einer Art, die den Nachkriegsschichten der aufstrebenden christlichen Traditionen glich, konnte man die himmlische Realität des Sabbats und des Heiligtums durch Ergebenheit und Gehorsam gegenüber Jesus erleben, dem ergebenen und gehorsamen himmlischen Hohepriester, der läutert, weiht und vollendet, anstatt Gottes heilige und himmlische Gegenwart im wöchentlichen Sabbat zu erfahren.

Jaeda C. Calaway Born 1980; 2003 BA from Illinois Wesleyan University; 2005 MA, 2007 M.Phil. and 2010 PhD from Columbia University in New York City; currently at Illinois College, Jacksonville, Illinois.

\section{Jetzt bestellen:}

https://mohrsiebeck.com/buch/the-sabbath-and-the-sanctuary-9783161523717?no_cache=1

order@mohrsiebeck.com

Telefon: $+49(0) 7071-923-17$

Telefax: $+49(0) 7071-51104$ 